\title{
Pengaruh Model Pembelajaran Contextual Teaching and Learning (CTL) Dalam Meningkatkan Kemampuan Pemecahan Masalah Matematika Siswa MTs Nurul Hakim Kediri Ditinjau dari Segi Gender
}

\author{
Oleh: \\ Husnul Laili \\ Husnullaili29@gmail.com
}

\begin{abstract}
Abstrak
Penelitian ini bertujuan untuk melihat pengaruh model pembelajaran Contextual Teaching and Learning (CTL) dalam meningkatkan kemampuan pemecahan masalah matematika dan untuk melihat perbedaan kemampuan pemecahan masalah Matematika setelah diajarkan dengan model pembelajaran Contextual Teaching and Learning (CTL)ditinjau dari segi gender.

Penelitian ini menggunakan penelitian eksperimen semu dengan desain pre-tes dan post-tes dengan kelompok non-ekuivalen. Penelitian ini menggunakan dua kelompok eksperimen dan dua kelompok kontrol. Populasi penelitian ini terdiri dari seluruh siswa kelas VII MTs Nurul Hakim Kediri. Pengambilan sampel dengan teknik sampling purposive. Dari populasi yang ada diambil empat kelas secara acak yang selanjutnya ditentukan dua kelas eksperimen (satu kelas putra dan satu kelas putri), dan dua kelas kontrol (satu kelas putra dan satu kelas putri) yang dipilih secara acak. Data dikumpulkan menggunakan tes bentuk uraian dan observasi kegiatan siswa. Untuk mengetahui pengaruh model pembelajaran dan perbedaan hasil berdasarkan gender data dianalisis dengan menggunakan ANACOVA $(\alpha=0,05)$.

Hasil penelitian menunjukkan bahwa pembelajaran matematika dengan Contextual Teaching and Learning (CTL)berpengaruh dalam meningkatkan kemampuan pemecahan masalah Matematika dan terdapat perbedaan kemampuan pemecahan masalah Matematika setelah diajar dengan model Contextual Teaching and Learning (CTL)ditinjau dari segi gender yaitu siswa dari kelas putri lebih tinggi tingkat kemampuan dalam memecahkan masalah Matematika dibanding kelas putra.
\end{abstract}

Kata Kunci: CTL, Pemecahan Masalah

\section{PENDAHULUAN}

\section{Latar Belakang Penelitian}

Mengingat kebhinekaan budaya, keragaman latar belakang, dan karakteristik peserta didik, serta tuntutan untuk menghasilkan lulusan yang bermutu, proses pembelajaran untuk setiap mata pelajaran harus fleksibel, bervariasi, dan memenuhi 
35 | Pengaruh Model Pembelajaran Contextual Teaching and Learning (CTL) Dalam Meningkatkan Kemampuan Pemecahan Masalah Matematika Siswa MTs Nurul Hakim Kediri Ditinjau dari Segi Gender

standar. Sebagaimana diatur dalam Peraturan Menteri Pendidikan nasional No. 41 tahun 2007 tentang standar proses. Peraturan tersebut menyatakan proses pembelajaran pada setiap satuan dasar dan menengah harus interaktif, inspiratif, menyenangkan, menantang, dan memotivasi peserta didik untuk berpartisipasi aktif, serta memberikan ruang yang cukup bagi prakarsa, kreativitas, dan kemandirian sesuai dengan bakat, minat, dan perkembangan fisik serta psikologis peserta didik.

Dengan memperhatikan standar kompetensi matematika untuk SMP/MTS tersebut di atas, maka kemampuan pemecahan masalah merupakan faktor yang sangat penting. Dalam NCTM (2000: 182) menyatakan "problem solving is the cornerstone of school mathematics". Ini berarti bahwa pemecahan masalah merupakan prinsip dasar dalam pembelajaran matematika di sekolah. Hal ini, menunjukkan bahwa kompetensi pemecahan masalah merupakan salah satu kompetensi yang penting dalam mempelajari matematika, karena pemecahan masalah merupakan sarana mempelajari ide matematika dan keterampilan matematika.

Yongge (2005: 57) menjelaskan bahwa salah satu penyebab kesulitan murid dalam belajar Matematika ialah sifat objeknya yang abstrak. Dengan kata lain materi pembelajaran Matematika terdapat penyulit intrinsik, yaitu keabstrakan objek Matematika.

Di samping itu juga, dalam dunia pendidikan khusunya pendidikan formal banyak dijumpai perbedaan-perbedaan mulai dari perbedaan gender, suku, agama, ras, dan lain-lain. Dari karakter yang heterogen tersebut, perbedaan gender dalam pembelajara Matematika cenderung terabaikan padahal sangat berpengaruh terhadap hasil belajar siswa (Campbell dan Storo, 2007: 3). Lebih lanjut Jensen (2008: 81) menyatakan dalam kesetaraan dan perbedaan gender yakni anak laki-laki dan anak perempuan berkembang pada kecepatan yang berbeda, tentu saja perlakuan yang sama dalam pembelajaran dianggap tidak sesuai, sehingga dalam hal ini peneliti beranggapan dengan perbedaan tersebut berpengaruh pada perbedaan kemampuan yang mengarah pada pemerataan prestasi siswa, sesuai ungkapan Muijs dan Rynolds (2005: 185) menjelaskan bahwa salah satu aspek paling kontroversial yaitu penanganan banyaknya perbedaan pembelajaran terutama dikonseptualisasikan dengan perbedaan kemampuan. Sebelumnya Yusuf, S. (2006) telah mengembangkan dengan melakukan penelitian tentang "Perbandingan gender dalam prestasi literasi 
36 | Pengaruh Model Pembelajaran Contextual Teaching and Learning (CTL) Dalam Meningkatkan Kemampuan Pemecahan Masalah Matematika Siswa MTs Nurul Hakim Kediri Ditinjau dari Segi Gender

siswa Indonesia" penelitian ini memberikan literasi hasil pada studi PISA (Program for International Student Asesment) 2000 dan 2003 yang menunjukkan siswa laki-laki di Indonesia sedikit mengungguli siswa perempuan, meskipun di Indonesia kebanyakan laki-laki lebih unggul dibanding siswa perempuan, hal ini terlihat pada studi TIMSS tahun 1994-1995 menunjukkan perbedaan gender yang signifikan pada 11 negara dari 16 negara peserta termasuk Indonesia.

Berdasarkan faktor-faktor yang diduga menjadi masalah terhadap prestasi belajar mata pelajaran Matematika, peneliti akan menerapkan model pembelajaran Contextual Teaching and Learning (CTL)sebagai salah satu strategi pembelajaran yang dapat membantu meningkatkan kemampuan siswa dalam memecahkan masalah Matematika. Sebagai suatu metode dalam pembelajaran, CTL mengarah pada pengalaman belajar pemecahan masalah yaitu belajar dalam tingkat lingkungan yang memungkinkan keleluasaan pertukaran pendapat dan gagasan serta keunikan dari tiap-tiap pembelajar sebagai hasil, selain itu pembelajaran CTL mampu meningkatkan kemampuan dan keterampilan individual sebagai efek pembelajaran dimana perbedaan situasi dan permasalahan yang baik merupakan kemampuan untuk melakukan kerjasama dengan anggota kelompok lain (Alavi, 1995: 12). Selain itu juga CTL atau pembelajaran berdasarkan masalah merupakan suatu pendekatan pembelajaran yang menggunakan masalah dunia nyata sebagai suatu konteks bagi perserta didik untuk belajar tentang cara berfikir kritis dan keterampilan memecahkan masalah, serta untuk memperoleh pengetahuan dan konsep yang esensial dari materi pelajaran.

Banyak penelitian yang menunjukkan manfaat dari pendekatan pembelajaran CTL diantaranya, Distrik (2009) menerapkan pembelajaran CTL melalui metode inkuiri, yang menghasilkan aktivitas dan pemahaman konsep pada siswa mengalami peningkatan, yang menghasilkan nilai rata-rata hasil belajar siswa juga meningkat. Selain itu juga, Santyasa (2008), menerapkan pembelajaran CTL dengan metode kooperatif yang menunjukkan dapat mengembangkan kemampuan pemecahan masalah, dengan pendekatan CTL berangkat dari masalah konteks nyata yang dikaitkan dengan pemecahan masalah secara matematis. Sudarman (2007) menerapkan pendekatan CTL dengan menggunakan masalah dunia nyata pada siswa 
37 | Pengaruh Model Pembelajaran Contextual Teaching and Learning (CTL) Dalam Meningkatkan Kemampuan Pemecahan Masalah Matematika Siswa MTs Nurul Hakim Kediri Ditinjau dari Segi Gender

untuk belajar cara berfikir kritis dan keterampilan pemecahan masalah serta memperoleh pengetahuan yang esensial dari materi pelajaran.

Berdasarkan uraian permasalahan di atas rancangan penelitian ini untuk mengetahui pengaruh pendekatan pembelajaran Contextual Teaching and Learning (CTL dalam meningkatkan kemampuan pemecahan masalah Matematika siswa ditinjau dari segi gender pada siswa MTs Nurul Hakim Kediri 2015/2016.

\section{Fokus Masalah}

Berdasarkan uraian di atas, dapat diidentifikasi masalah-masalah dalam belajar Matematika sebagai berikut:

1. Mata pelajaran Matematika sebagai salah satu mata pelajaran yang sulit.

2. Pengajaran Matematika lebih menekankan pada aspek kognitif dalam cakupan materi maupun dalam proses pembelajaran.

3. Guru lebih tertarik pada jawaban siswa yang benar tanpa memperhatikan prosedur penyelesaian sehingga siswa tidak mempunyai kesempatan mengembangkan daya nalarnya dan kesulitan memahami konsep Matematika.

4. Kurangnya kemampuan guru dalam mengaplikasikan strategi pembelajaran.

5. Perbedaan gender dalam pembelajaran Matematika masih terabaikan sehingga guru masih memberikan perlakuan yang homogen pada kelas yang terdiri dari siswa yang sifatnya beterogen terutama dalam hal perbedaan gender.

Klasifikasi rata-rata Matematika siswa SMP/MTs di NTB TP. 2015/2016 dari tingkat provinsi hingga tingkat sekolah belum mencapai hasil yang optimal.

\section{METODE PENELITIAN}

CTL merupakan setiap suasana pembelajaran yang melibatkan siswa dalam situasi pemecahan masalah dalam kehidupan nyata dan didesain dalam bentuk orgaisasi atau kelompok dengan menghubungkan pengalaman pengetahuan pada proses kolaborasi dan refleksi pengetahuan yang dituju.

Menurut Johnson (2002: 24) "CTL is a bolistic system. Is consists of interrelated parts that, when interwoven, produce an effect that exceeds what any single part could achieve". Pendapat Johnson yang mengatakan CTL adalah sebuah sistem yang menyeluruh dan terdiri dari bagian-bagian yang saling terhubung yang jika bagian-bagian terjalin satu sama lain akan dihasilkan pengaruh yang melebihi hasil yang diberikan bagian- 
38 | Pengaruh Model Pembelajaran Contextual Teaching and Learning (CTL) Dalam Meningkatkan Kemampuan Pemecahan Masalah Matematika Siswa MTs Nurul Hakim Kediri Ditinjau dari Segi Gender

bagiannya secara terpisah. Terkait dengan penjelasan di atas, Rusman (2010: 193 198) mengatakan bahwa ada tujuh prinsip pembelajaran CTL yang harus dikembangkan oleh guru yaitu:

\section{Konstruktivisme (Contructivism)}

Konstruktivisme merupakan landasan pikiran filosofi dalam CTL yang menyatakan bahwa pengetahuan dibangun oleh manusia sedikit demi sedikit, yang hasilnya diperluas melalui konteks yang terbatas. Dalam CTL, strategi untuk pembelajaran siswa menghubungkan antara setiap konsep dengan kenyataan merupakan unsur yang diutamakan dibandingkan dengan penekanan terhadap seberapa banyak pengetahuan yang harus diingat oleh siswa.

2. Menemukan (Inquiry)

Menemukan merupakan kegiatan inti dari CTL, melalui upaya menemukan akan memberikan penegasan bahwa pengetahuan dan keterampilan serta kemampuan-kemampuan lain yang diperlukan bukan merupakan hasil dari mengingat seperangkat fakta-fakta, tetapi merupakan hasil menemukan sendiri.

3. Bertanya (Questioning)

Penerapan unsur bertanya dalam CTL harus difasilitasi oleh guru, kebiasaan siswa untuk bertanya akan mendorong peningkatan kualitas dan produktivitas siswa. Melalui penerapan bertanya, pembelajaran akan lebih hidup, akan mendorong proses dan hasil pembelajaran yang lebih luas dan mendalam, dan akan banyak ditemukan unsur-unsur terkait yang sebelumnya tidak terpikirkan baik oleh guru maupun siswa.

4. Masyarakat Belajar (Learning Community)

Maksud dari masyarakat belajar adalah membiasakan siswa untuk melakukan kerja sama dan memanfaatkan sumber belajar dari teman-teman belajarnya. Seperti yang disarankan dalam learning cummunity, hasil pembelajaran diperoleh dari kerja sama dengan orang lain melalui berbagai pengalaman (sharing).

5. Pemodelan (Modelling)

Pemodelan adalah proses pembelajran dengan memperagakan sesuatu sebagi contoh yang dapat ditiru oleh siswa. Tahap pembuatan model dapat dijadikan 
39 | Pengaruh Model Pembelajaran Contextual Teaching and Learning (CTL) Dalam Meningkatkan Kemampuan Pemecahan Masalah Matematika Siswa MTs Nurul Hakim Kediri Ditinjau dari Segi Gender

alternatif untuk mengembangkan pembelajaran agar siswa bisa memenuhi harapan siswa secara menyeluruh, dan membantu mengatasi keterbatasan yang dimiliki oleh para guru.

6. Refleksi (Reflection)

Refleksi adalah cara berpikir tentang apa yang baru terjadi atau baru saja dipelajari. Dengan kata lain refleksi adalah berpikir ke belakang tentang apa yang sudah dilakukan di masa lalu. Pada tahap refleksi, siswa diberi kesempatan untuk mencerna, menimbang, membandingkan, menghayati, dan melakukan diskusi dengan dirinya sendiri (learning to be).

7. Penilaian Sebenarnya (Authentic Assessment)

Tahap terakhir dari pembelajaran kontekstual adalah melakukan penilaian. Penilaian sebagai bagian integral dari pembelajaran memiliki fungsi yang amat menentukan untuk mendapatkan informasi kualitas proses dan hasil pembelajaran melalui penerapan CTL. Penilaian adalah proses pengumpulan berbagai data dan informasi yang bisa memberikan gambaran atau petunjuk terhadap pengalaman belajar siswa.

Selain itu, Johnson (2002: 24), mengatakan bahwa sistem pembelajaran kontekstual mencakup delapan komponen, yaitu:

1) making meaningful connections, yaitu pembelajaran ditujukan untuk dapat menghubungkan yang bermakna antara ilmu yang diperoleh dengan kehidupan sehari-hari;

2) doing significant work, yaitu dalam pembalajaran, kegiatan yang dilakukan adalah kegiatan yang berarti atau biasa terjadi dalam kehidupan;

3) self-regulated learning, yaitu siswa dapat mangatur diri sendiri untuk belajar dan mendapatkan pengalaman;

4) collaborations, yaitu siswa diajak untuk dapat saling bekerja sama dalam memecahkan suatu masalah dalam proses pembelajaran;

5) critical and creative thinking, yaitu siswa dilatih untuk dapat berpikir kritis dan kreatif dalam menghadapi suatu masalah;

6) nurturing the individual yaitu guru tidak hanya mentrasfer ilmu saja melainkan medidik, melatih, dan memperdulikan siswa dalam proses pembelajaran; 
40 | Pengaruh Model Pembelajaran Contextual Teaching and Learning (CTL) Dalam Meningkatkan Kemampuan Pemecahan Masalah Matematika Siswa MTs Nurul Hakim Kediri Ditinjau dari Segi Gender

7) reaching high standards yaitu siswa dilatih untuk mencapai hasil yang maksimal dalam belajar;

8) using authentic assessment yaitu guru memberikan nilai berdasarkan kenyataan yang sebenarnya.

Berdasarkan komponen pembelajaran kontekstual, maka dapat dipaparkan secara singkat makna yang ditujukkan: (1) membuat keterkaitan-keterkaitan yang bermakna, (2) melakukan pekerjaan yang berarti, (3) melakukan pembelajaran yang diatur sendiri, (4) melakukan kerja sama, (5) berpikir kritis dan kreatif, (6) membantu individu untuk tumbuh dan berkembang, (7) mencapai standar yang tinggi, (8) menggunakan penilaian autentik

\section{Jenis dan Desain Penelitian}

Rancangan penelitian ini menggunakan metode eksperimen. Metode eksperimen dipillih karena rancangan pendekatan pembelajaran Contextual Teaching and Learning (CTL) pada mata pelajaran Matematika berdasarkan perbedaan kemampuan siswa memecahkan masalah menurut gender yang secara teoritis belum diketahui hasilnya.

Wiersma (1986: 101) menyatakan, dalam desain eksperimen peneliti memanipulasi sedikitnya satu variabel bebas. Dalam rancangan penelitian ini peneliti memanipulasi satu variabel bebas yaitu model pembelajaran Contextual Teaching and Learning (CTL)yang akan diterapkan pada siswa berdasarkan perbedaan gender sebagai variabel moderator dan akan melihat pengaruhnya terhadap kemampuan pemecahan masalah Matematika siswa dalam ketuntasan belajar sebagai variabel terikat.

Metode eksperimen yang dipilih adalah eksperimen semu. Menurut Ghozali (2008: 17) penelitian eksperimen semu jika datanya berasal dari lingkungan yang telah ada atau dari suatu kejadian yang timbul tanpa intervensi langsung dari peneliti. Dalam penelitian ini, tidak dibentuk kelas-kelas baru, tetapi menggunakan kelas-kelas sebagaimana adanya yakni telah dikelompokkan menurut tingkat kemampuan siswa pada tiap-tiap kelas.

\section{Teknik dan Instrumen Pengumpulan Data}

Teknik yang digunakan untuk mengumpulkan data dalam penelitian ini adalah tes tulis dan observasi kegiatan siswa belajar selama pelaksanaan penelitian.

1. Tes Tulis 
41 | Pengaruh Model Pembelajaran Contextual Teaching and Learning (CTL) Dalam Meningkatkan Kemampuan Pemecahan Masalah Matematika Siswa MTs Nurul Hakim Kediri Ditinjau dari Segi Gender

Instrumen penelitian untuk mengukur kemampuan pemecahan masalah Matematika siswa berupa tes tulis yang berbentuk uraian. Ebel \& Frisbie (1986: 127) menyatakan tes uraian memberikan indikasi yang baik untuk mengungkap prestasi yang nyata dalam belajar dan untuk mengetahui sejauh mana siswa mendalami suatu masalah yang diujikan. Melakukan evaluasi dengan menggunakan tes tulis dalam bentuk uraian guru akan lebih mudah mengetahui sejauh mana siswa mendalami dan memahami materi yang telah diberikan. Lebih lanjut Sulistyorini (2009: 95) menyatakan tes uraian berbentuk essai digunakan untuk membiasakan siswa memecahkan masalah (problem solving), mencoba merumuskan hipotesis, menyusun dan mengekspresikan gagasan, dan menarik kesimpulan dari pemecahan masalah.

Soal tes dikembangkan dengan modifikasi translasi, berbentuk soal terbuka atau open-ended dan process problem yang secara simultan memerlukan beberapa konsep Matematika sekaligus (Walle, 1994: 45-47; Van Heuvel, 1990: 54-55). Soal uraian yang diberikan didesain dalam bentuk pertanyaan terbuka yaitu mempunyai beberapa proses penyelesaian yang tidak terlepas dari konsep Matematika.

2. Lembar Observasi

Instrument penelitian untuk mengamati prilaku siswa selama proses pembelajaran Matematika model CTL menggunakan lembar observasi kegiatan siswa. Instrument untuk memantau proses pembelajaran berdasarkan strategi yang digunakan pada masing-masing kelompok berupa lembar observasi pembelajaran. Menurut Sulistyorini (2009: 85) observasi merupakan suatu teknik yang dilakukan dengan cara mengadakan pengamatan secara teliti serta pencatatan secara sistematis. Hal-hal yang perlu dipantau mencakup berbagai ciri-ciri pembelajaran berbasis masalah atau Contextual Teaching and Learning (CTL)yang diberikan. Kegiatan observasi ini akan diberikan pada setiap kelompok perlakuan yang menggunakan model pembelajaran CTL yang diasumsikan mempunyai pengaruh yang positif yakni dapat meningkatkan kemampuan siswa dalam memecahkan masalah Matematika.

Jenis observasi yang dilakukan dalam penelitian ini adalah observasi eksperimen, yang mana dalam kegiatan observasi ini dilakukan oleh guru mata pelajaran dengan tujuan mengendalikan unsur-unsur penting dalam situasi penelitian pada siswa. Sesuai dengan ungkapan Sulistyorini (2009: 85) observasi eksperimen terjadi jika pengamat tidak berpartisipasi dalam kelompok. 
42 | Pengaruh Model Pembelajaran Contextual Teaching and Learning (CTL) Dalam Meningkatkan Kemampuan Pemecahan Masalah Matematika Siswa MTs Nurul Hakim Kediri Ditinjau dari Segi Gender

\section{Teknik analisis data}

Teknik yang digunakan untuk menganalisis data hasil tes prestasi belajar matematika adalah ANACOVA, Anacova merupakan hasil kombinasi dari analisis regresi dan analisis varian (anava), Prosedur analisisnya berupa: nilai pretes $(\mathrm{X})$ dipandang sebagai kovariat atau variabel pengiring yang sangat mempengaruhi nilai pada variabel postes $(\mathrm{Y})$ oleh karena itu sebelum meninjau variabel terikat $\mathrm{Y}$ sebagai pengaruh dari hasil perlakuan dengan anava, perlu dilakukan analisis regresi.

Asumsi-asumsi dasar yang harus dipenuhi dalam anakova yaitu untuk variabel terikat Y, sebagai berikut (Kirk, 1995: 722).

1. Observasi - observasinya harus bebeas satu sama lain, yang berarti data tes yang diperoleh dari satu sekolah tidak dipengaruhi oleh data tes dari sekolah lain.

2. Observasi- observasinya diambil dari populasi yang berdistribusi normal.

Uji normalitas bertujuan untuk memeriksa kenormalan distribusi populasi yang menghasilkan setiap kelompok data sampel. Dengan menguji normalitas akan diketahui sampel yang diambil berasal dari populasi yang berdistribusi normal atau tidak. Apabila hasil pengujian normal, maka hasil pengujian statistik dapat digeneralisasikan pada populasi penelitian. Pengujian normalitas dilakukan dengan metode Kolmogorov - Smirnov pada taraf signifikansi $\alpha=0,05$ menggunakan program SPSS 17.0 for windows. Hipotesis yang akan diuji adalah: Ho: data terdistribusi secara normal, melawan Hi: data tidak terdistribusi secara normal. Ho ditolak jika $\mathrm{p}<\alpha=$ 0,05 .

3. Populasi - populasinya mempunyai varian yang sama.

Untuk memeriksa apakah varian skor populasi sama, akan dilakukan uji homogenitas varians dengan menggunakan metode Kolmogorov-Smirnov dengan bantuan program SPSS 17.0. Rumusan hipotesis pada uji homogenitas ini adalah Ho: kedua kelompok sampel mempunyai varians yang sama, melawan Hi: varians kedua kelompok berbeda. Penarikan kesimpulan terhadap uji hipotesis dilakukan pada taraf signifikansi 5\%. $\mathrm{H}_{0}$ ditolak jika $\mathrm{p}<\alpha=0,05$. 
43 | Pengaruh Model Pembelajaran Contextual Teaching and Learning (CTL) Dalam Meningkatkan Kemampuan Pemecahan Masalah Matematika Siswa MTs Nurul Hakim Kediri Ditinjau dari Segi Gender

4. Bentuk regresinya linier.

Asumsi ini menganggap keterkaitan kovariat dengan variabel terikat bersifat linier. Untuk mengetahui apakah pasangan nilai variabel $\mathrm{X}$ atau nilai pretes, dan nilai variabel $\mathrm{Y}$ atau nilai postes mempunyai hubungan linier atau tidak menggunakan uji $\mathrm{F}$ dengan bantuan SPSS 17.0. Kriteria yang digunakan adalah jika $\mathrm{p}<0,05$ maka hubungan $\mathrm{X}$ dan $\mathrm{Y}$ dinyatakan linier.

5. Koefisien regresi pada tiap kelompok bersifat homogen.

Untuk menguji asumsi bahwa keempat koefisien regresi adalah homogen menggunakan uji statistik sebagai berikut (Kirk, 1995:723).

$$
\begin{aligned}
& F=\frac{s_{z} /(k-1)}{s_{1} /(N-2 k)} \text {, dengan } \\
& s_{1}=s_{y y}-\sum_{j=1}^{k} \frac{\left(s_{x y j}\right)^{2}}{s_{x x j}} \text { dan } s_{2}=\sum_{j=1}^{k} \frac{\left(s_{x y j}\right)^{2}}{s_{x x j}}-\frac{\left(s_{x y}\right)^{2}}{s_{x y}}
\end{aligned}
$$

Hipotesis yang diturunkan untuk diuji adalah $\mathrm{H}_{\circ}: \beta 1=\beta 2$ lawan $\mathrm{Hi}$ :

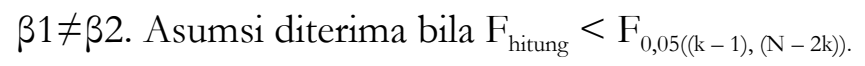

6. Variabel kovariat $\mathrm{X}$ diukur tanpa kekeliruan

Adapun desain eksperimen pada penelitian ini memiliki model sebagai berikut (Kirk, 1995: 717-718).

$Y_{i j}=\mu+\alpha_{j}+\beta\left(X_{i j}-\bar{X}\right)+\varepsilon_{i(j)} \quad\left(i=1, \ldots, \mathrm{n}_{j} ; j=1,2,3,4\right)$

$Y_{i j}=$ hasil tes akhir sebelum disesuaikan untuk subjek ke-i pada perlakuan ke-j

$\mu=$ rata-rata populasi

$\alpha_{j}=$ efek perlakuan ke-j

$\beta=$ koefisien regresi $\mathrm{Y}$ atas $\mathrm{X}$

$\bar{X}_{i j} \quad=$ nilai kovariat untuk subjek ke-I pada perlakuan ke-j

$\overline{X_{. .}} \quad=$ rata-rata untuk kovariat $\mathrm{X}$

$\varepsilon_{i(j]}=$ kekeliruan berupa efek acak dari subjek ke-I karena dikenai perlakuan ke-j

Sehingga diperoleh nilai $\mathrm{Y}$ yang disesuaikan yaitu nilai tes akhir yang bebas dari pengaruh kovariat (pretes), yaitu:

$$
Y_{\text {adjij }}=Y_{i j}-\beta\left(X_{i j}-\bar{X}\right)=\mu+\alpha_{j}+\varepsilon_{i(j)}
$$


44 | Pengaruh Model Pembelajaran Contextual Teaching and Learning (CTL) Dalam Meningkatkan Kemampuan Pemecahan Masalah Matematika Siswa MTs Nurul Hakim Kediri Ditinjau dari Segi Gender

Hipotesis yang diturunkan untuk diuji adalah $\mathrm{H}_{0}: \mu_{1}=\mu_{2}=\mu_{3}=\mu_{4}$ melawan $\mathrm{H} 1: \mu_{\mathrm{i}} \neq \mu_{\mathrm{j}}$, untuk $\mathrm{j}=1,2,3,4$ dengan $\mathrm{j} \neq \mathrm{j}$ ' dengan menggunakan uji

$$
\begin{aligned}
& F=\frac{A_{a d j} /(k-1)}{s_{a d j} /(N-k-1)} \text { dimana: } \\
& A_{a d j}=\text { jumlah kuadrat antar kelompok } \\
& s_{a d j}=\text { jumlah kuadrat dalam kelompok } \\
& k \quad=\text { banyak kelompok } \\
& N \quad=\text { jumlah seluruh responden }
\end{aligned}
$$$$
\mathrm{H}_{0} \text { ditolak jika nilai } \mathrm{F}_{\text {hitung }}>\mathrm{F}_{0.05((\mathrm{k}-1) \text {, (N-k-1)). }}
$$

Apabila pengujian dengan anakova hasilnya signifikan, dilanjutkan dengan uji Tukey-Kramer (qTK) pada $\alpha=0,05$ untuk memastikan pasangan-pasangan yang memiliki perbedaan secara signifikan, Menurut Kirk (1995:146), uji Tukey-Kramer dapat digunakan apabila distribusi pada populasi normal, variansi populasinya homogen dan jumlah subjek tiap kelompok tidak sama, rumus yang digunakan adalah:

$$
\mathrm{q} T K=\frac{\hat{\psi}}{\partial_{\bar{Y}}}=\frac{c_{j} \hat{P}_{a d j(j, j)}+c_{j(j)^{\prime}}}{\sqrt{\left[M S_{\text {eror }}\left(\frac{1}{n_{j}}+\frac{1}{n_{j^{\prime}}}\right)\right] / 2}}
$$

Hipotesis nol yang akan diuji adalah $\mathrm{H}_{0}: \mu_{\mathrm{j}}=\mu_{\mathrm{j}}$ untuk suatu $\mathrm{j}=1,2,3,4$ dengan $\mathrm{j} \neq j$ '. $\mathrm{H}_{0}$ ditolak jika nilai mutllak $\mathrm{q} T K_{\text {hitung }} \geq \mathrm{q}_{0,05 ; \mathrm{k},(\mathrm{N}-\mathrm{K}-1)}$.

Sebelum sampai pada pengujian hipotesis terlebih dahulu dilakukan deskripsi data mengenai variabel penelitian dan uji prasyarat analisis, deskripsi data dilakukan dengan analisis deskriptif terhadap variabelvariabel penelitian, baik variabel bebas maupun variabel terikat, hasil analisis dekriptif yang disajikan pada penelitian ini adalah rata-rata, dan sandar deviasi.

Untuk membandingkan ketuntasan belajar antara kedua kelompok perlakuan, dilakukan pengujian perbedaan ketuntasan belajar dengan menggunakan uji chi - kuadrat $\left(x^{2}\right)$ sebagai berikut (Sudjana, 2005: 284285). 
45 | Pengaruh Model Pembelajaran Contextual Teaching and Learning (CTL) Dalam Meningkatkan Kemampuan Pemecahan Masalah Matematika Siswa MTs Nurul Hakim Kediri Ditinjau dari Segi Gender

$$
x^{2}=\frac{n \times\left(|a \cdot d-b . c|-\frac{1}{2} n\right)^{2}}{(a+b) \times(a+c) \times(b+d) \times(c+d)}
$$

Keterangan:

$\mathrm{a}=$ banyak siswa tuntas belajar pada kelompok $\mathrm{j}$.

$\mathrm{b}=$ banyak siswa belum tuntas belajar pada kelompok $\mathrm{j}$.

$\mathrm{c}=$ banyak siswa tuntas belajar pada kelompok j’.

$\mathrm{d}=$ banyak siswa belum tuntas belajar pada kelompok j'.

Hipotesis yang diturunkan untuk diuji adalah $\mathrm{H}_{0}$ : ketuntasan belajar kelompok j tidak lebih tinggi daripada ketuntasan kelompok belajar kelompok j'. Ho ditolak jika $\mathrm{x}_{\text {hitung }}^{2}>\mathrm{x}_{\text {tabel. }}^{2}$

\section{Hasil Penelitian dan Pembahasan}

\section{Data Hasil Kemampuan Pemecahan Masalah}

Deskripsi data terdiri dari data hasil kemampuan pemecahan yaitu data hasil pre-tes dan post-tes pada masing-masing kelompok siswa, kelompok siswa tersebut terdiri dari kelompok dengan pembelajaran CTL dan kelompok Ceramah dan Tanyajawab, selanjutnya kelompok tersebut dikombinasikan berdasarkan gender. Deskripsi data tersebut ditunjukkan sebagai berikut.

Data Hasil Kemampuan Pemecahan Masalah

\begin{tabular}{|l|c|c|c|c|c|c|c|c|}
\hline \multirow{3}{*}{ Klasifikasi } & \multicolumn{4}{|c|}{ CTL } & \multicolumn{3}{c|}{ Ceramah Tanya-Jawab } \\
\cline { 2 - 9 } & \multicolumn{2}{|c|}{ Putra (E1) } & \multicolumn{2}{c|}{ Putri (E2) } & \multicolumn{2}{c|}{ Putra (K1) } & \multicolumn{2}{c|}{ Putri (K2) } \\
\cline { 2 - 9 } & Pretes & Postes & Pretes & Postes & Pretes & Postes & Pretes & Postes \\
\hline Skor & 1471 & 2011 & 1486 & 2179 & 1487 & 1874 & 1494 & 1861 \\
\hline Rata-rata & 58,84 & 80,44 & 59,44 & 87,16 & 59,48 & 74,96 & 59,76 & 74,44 \\
\hline St. Dev & 1,90 & 8,44 & 1,58 & 8,94 & 1,58 & 7,35 & 1,94 & 8,67 \\
\hline
\end{tabular}

\begin{tabular}{|l|c|c|c|c|}
\hline \multirow{2}{*}{ Metode } & \multicolumn{2}{|c|}{ Putra } & \multicolumn{2}{c|}{ Putri } \\
\cline { 2 - 5 } & Pretes & Postes & Pretes & Postes \\
\hline CTL & 1471 & 2011 & 1486 & 2179 \\
\hline Ceramah Tanya-jawab & 1487 & 1874 & 1494 & 1861 \\
\hline Jumlah & 2958 & 3885 & 2980 & 4040 \\
\hline
\end{tabular}

Data di atas merupakan hasil belajar siswa dengan metode CTL pada masing-masing kelompok perlakuan ditinjau dari segi gender terhadap 
46 | Pengaruh Model Pembelajaran Contextual Teaching and Learning (CTL) Dalam Meningkatkan Kemampuan Pemecahan Masalah Matematika Siswa MTs Nurul Hakim Kediri Ditinjau dari Segi Gender

kemampuan pemecahan masalah, data diatas menunjukkan kondisi awal siswa pada kelompok CTL putra dalam belajar matematika yang ditunjukkan pada hasil pretest memiliki rata-rata 58,84, standar deviasi 1,90, setelah siswa melakukan pembelajaran dengan metode CTL pada kelompok siswa laki-laki mengalami peningkatan hasil belajar yang ditunjukkan pada hasil postest memiliki rata-rata 80,44, standar deviasi 8,44.

Pada kelompok CTL putri menunjukkan hasil belajar siswa pada kondisi awal yaitu rata-rata hasil pretes 59,44, standar deviasi 1,58, setelah siswa melakukan pembelajaran dengan metode CTL pada siswa putri rata-rata hasil siswa mengalami peningkatan yang ditunjukkan pada rata-rata hasil postes menjadi 87,16, standar deviasi 8,94.

Sedangkan hasil belajar siswa pada kelompok siswa pada kelompok Ceramah Tanya-jawab putra menunjukkan rata-rata kondisi awal pada pretes 59,48, standar deviasi 1,58, setelah siswa melakukan pembelajaran dengan metode Ceramah Tanya-jawab mengalami peningkatan rata-rata hasil pada postes 74, 96, standar deviasi 7,35.

Kondisi awal pada kelompok Ceramah Tanya-jawab putri menunjukkan rata-rata hasil pada pretes 59,76, standar deviasi 1,94, setelah melakukan pembelajaran dengan metode Ceramah Tanya-jawab mengalami peningkatan rata-rata hasil pada postes 74,44 , standar deviasi 8,67 .

1. Uji Asumsi Analisis Kovarian

Uji hipotesis pada penelitian ini dilakukan dengan menggunakan analisis kovarian (Anakova). Sebelum melakukan analisis data, dilakukan uji prasyarat anakova, yaitu uji normalitas, homogenitas, linieritas, dan koefisien regresi pada kelompok-kelompok yang bersifat homogen.

a. Uji Normalitas

Uji normalitas dipakai untuk mengukur apakah data yang dimiliki berdistribusi normal sehingga dapat dipakai dalam statistic parametric, Uji normalitas dalam hal ini dilakukan pada kelas eksperimen yaitu pada kelas CTL pada kelompok putra dan CTL pada kelompok putri, baik pada hasil pretes maupun hasil postes. Cara yang dipakai dalam menguji 
47 | Pengaruh Model Pembelajaran Contextual Teaching and Learning (CTL) Dalam Meningkatkan Kemampuan Pemecahan Masalah Matematika Siswa MTs Nurul Hakim Kediri Ditinjau dari Segi Gender

normalitas dalam hal ini adalah Kolmogorov-Smirnov dan menunjukkan hasil sebagai berikut.

One-Sample Kolmogorov-Smirnov Test

\begin{tabular}{|c|c|r|}
\hline \multicolumn{2}{|c|}{} & \multicolumn{1}{|c|}{ Postes } \\
\hline \multicolumn{2}{|c|}{$\mathrm{N}$} & 50 \\
\hline Normal Parameters (a,b) & Mean & 83,8000 \\
\cline { 2 - 3 } & Std. Deviation & 9,25379 \\
\hline Most Extreme & Absolute &, 120 \\
\cline { 2 - 3 } Differences & Positive &, 120 \\
\cline { 2 - 3 } & Negative &,- 109 \\
\hline Kolmogorov-Smirnov Z &, 851 \\
\hline Asymp. Sig. (2-tailed) &, 464 \\
\hline
\end{tabular}

Hasil penelitian menunjukkan bahwa nilai signifikansi KolmogoroveSmirnove postes pada keompok CTL putra dan CTL putri $0,464>0,05$. Dengan demikian, dapat disimpulkan bahwa sampel penelitian ini berasal dari populasi yang berdistribusi normal.

b. Uji Homogenitas Varians

Uji homogenitas dilakukan dengan menggunakan uji Lavene. Hasil uji homogenitas untuk skor postes prestasi belajar matematika diperoleh $\mathrm{F}_{0,05}=1,870$ dengan signifikan $0,140>0,05$, sehingga dapat disimpulkan bahwa populasinya memiliki varians yang homogen.

Uji Homogenitas Varians dengan Menggunakan

\begin{tabular}{|c|c|c|c|}
\hline \multicolumn{4}{|c|}{ Uji Levene } \\
\hline F & df1 & df2 & Sig. \\
\hline 1,870 & 3 & 96 &, 140 \\
\hline
\end{tabular}

c. Uji Linearitas

Uji linearitas berfungsi untuk menunjukkan apakah hubungan antara $\mathrm{X}$ (pretes) dan Y (postes) linear atau tidak linear. Dalam hal ini dilakukan dengan uji F dengan bantuan SPSS 17 for windows. Hasil uji linearitas untuk nilai postes prestasi belajar matematika diperoleh nilai $\mathrm{F}=15,872$ 
48 | Pengaruh Model Pembelajaran Contextual Teaching and Learning (CTL) Dalam Meningkatkan Kemampuan Pemecahan Masalah Matematika Siswa MTs Nurul Hakim Kediri Ditinjau dari Segi Gender

dengan signifikan $0,000<0,05$, sehingga dapat disimpulkan bahwa $\mathrm{X}$ dan Y mempunyai hubungan yang linear.

d. Pengambilan sampel dilakukan secara acak

Pengambilan sampel dilakukan secara acak (random) yaitu dengan mengambil 4 kelas yang terdiri dari dua kelas laki-laki dan dua kelas perempuan yaitu kelas VIIB sebagai kelas eksperimen dan VIIA sebagai kelas kontrol, dan seluruh sampel tersebut diambil dari 5 kelas sebagai populasi pengambilan sampel.

2. Uji Hipotesis

Data pengaruh pada masing-masing subyek perlakuan dengan

Menggunakan Uji Tests of Between-Subjects Effects

\begin{tabular}{|l|r|r|r|r|r|}
\hline \multicolumn{1}{|c|}{ Source } & $\begin{array}{c}\text { Type III } \\
\text { Sum of } \\
\text { Squares }\end{array}$ & df & Mean Square & F & \multicolumn{1}{c|}{ Sig. } \\
\hline Corrected Model & $2606,348^{2}$ & 3 & 868,783 & 12,330 &, 000 \\
\hline Intercept & 1620,823 & 1 & 1620,823 & 23,003 &, 000 \\
\hline Metode & 1823,556 & 1 & 1823,556 & 25,880 &, 000 \\
\hline Gender & 307,899 & 1 & 307,899 & 4,370 &, 039 \\
\hline Pretest & 295,848 & 1 & 295,848 & 4,199 &, 043 \\
\hline Error & 6764,402 & 96 & 70,463 & & \\
\hline Total & 637427,000 & 100 & & & \\
\hline Corrected Total & 9370,750 & 99 & & & \\
\hline
\end{tabular}

Test of between-subjects effects digunakan untuk menguji pengaruh setiap faktor terhadap variabel dependent, dari data di atas menunjukkan metode yang diterapkan pada masing-masing kelompok perlakuan terhadap kemampuan pemecahan masalah matematika, diperoleh $F$ tes 25,880 signifikan pada $0,03<0,05$. Sementara itu, perbedaan kemampuan pemecahan masalah siswa dari gender ditunjukkan berdasarkan hasil analisis pada tabel menunjukkan $F$ tes 4,370 signnifikan pada $0,039<0,05$ yang berarti ada perbedaan kemampuan pemecahan masalah diantara kelompok perlakuan terutama ditinjau dari segi gender. 
49 | Pengaruh Model Pembelajaran Contextual Teaching and Learning (CTL) Dalam Meningkatkan Kemampuan Pemecahan Masalah Matematika Siswa MTs Nurul Hakim Kediri Ditinjau dari Segi Gender

\section{PEMBAHASAN}

\section{Pengaruh Pembelajaran Matematika dengan Model Contextual Teaching and Learning (CTL)Terhadap Kemampuan Pemecahan Masalah}

Setelah melakuakan uji statistik pada hasil belajar siswa yang terdiri atas 2 (dua) kelompok eksperimen yaitu kelompok siswa yang belajar matematika dengan model pembelajaran Contextual Teaching and Learning (CTL)dan 2 (dua) kelompok kontrol yaitu kelompok siswa yang belajar matematika dengan metode Ceramah Tanya-jawab, menunjukkan pengaruh model pembelajaran CTL dalam meningkatkan kemampuan pemecahan masalah pada mata pelajaran matematika. Pemecahan masalah sebagai strategi belajar kognitif yang lebih menganjurkan kurikulum sekolah sebagai subyek, yaitu dengan mengorganisasikan masalah sekitar kehidupan nyata pada kegiatan belajar, dan altetrnatif pendekatan untuk pencapaian hasil pada pendidikan pemecahan masalah adalah sebuah model pembelajaran yang disebut pembelajaran berdasarkan masalah (Problem-Based Learning) yang terbukti sangat berpengaruh terhadap peningkatan kemampuan pemecahan masalah matematika.

Data hasil uji statistik menunjukkan rata-rata kemampuan pemecahan masalah siswa setelah dilakukan treatment yang menunjukkan seberapa besar pengaruh treatment yang sudah diberikan pada masing-masing kelompok siswa. Rata-rata hasil postes pada kelompok CTL putra $(\mathrm{E} 1)=80.44$, kelompok CTL putri $(\mathrm{E} 2)=87.16$, kelompok Ceramah Tanya-jawab putra $(\mathrm{K} 1)=74.96$, dan kelompok Tanya-jawab putri $(\mathrm{K} 2)=74.44$. Berdasarkan rata-rata hasil yang diperoleh siswa yang diajar dengan model CTL baik dari sekolah putra maupun dari sekolah putri menunjukkan pengaruh yang lebih besar pada hasil kemampuan 
50 | Pengaruh Model Pembelajaran Contextual Teaching and Learning (CTL) Dalam Meningkatkan Kemampuan Pemecahan Masalah Matematika Siswa MTs Nurul Hakim Kediri Ditinjau dari Segi Gender

pemecahan masalah matematika siswa. Sedangkan siswa yang diajar dengan metode Ceramah tanya-jawab sebagai kontrol pembelajaran model CTL dalam penelitian ini kurang efektif.

Data hasil postes selanjutnya dianalisis sebagai hasil penelitian dengan teknik Anava Dua Arah dalam hal ini menggunakan bantuan perangkat program SPSS 17.0 for Windows, setelah dilakukan analisis dapat dikemukakan bahwa model pembelajaran berdasarkan masalah (CTL) sangat berpengaruh apabila digunakan sebagai solusi untuk meningkatkan kemampuan masalah Matematika, hal ini juga ditunjukkan pada tabel hasil Test of between-subjects effects yang menunjukkan adanya pengaruh model pembelajaran berdasarkan masalah (CTL) terhadap kemampuan pemecahan masalah pada masing-masing kelompok perlakuan dengan $\mathrm{F}$ tes 4,199 signifikan pada $0,43<0,05$.

\section{Perbandingan Hasil Belajar Siswa setelah Diajarkan dengan Model Contextual Teaching and Learning (CTL)ditinjau dari segi Gender}

Gender sebagai karakteristik sebuah budaya yang menggambarkan dua jenis kelamin yang berbeda. Dari hasil analisis tingkat kemampuan pemecahan masalah menunjukkan perbedaaan kemampuan pemecahan masalah matematika yang signifikan setelah melakukan pembelajaran dengan model CTL menunjukkan tingkat kemampuan yang berbeda dalam memecahkan masalah yakni pada kelompok putri (E1) lebih unggul dari kelompok putra (E2), hal ini disebabkan dalam kegiatan pembelajan berdasarkan masalah siswa putri lebih aktif dalam mengumpulkan informasi dalam proses pemecahan masalah terhadap masalah yang sedang diselidiki, selain itu juga faktor perkembangan pada siswa putri yang lebih cepat dibanding siswa putra sebagai salah satu faktor yang dapat 
51 | Pengaruh Model Pembelajaran Contextual Teaching and Learning (CTL) Dalam Meningkatkan Kemampuan Pemecahan Masalah Matematika Siswa MTs Nurul Hakim Kediri Ditinjau dari Segi Gender

mempengaruhi tingkat keefektifan siswa putri lebih tinggi yang berimplikasi pada hasil belajar matematika.

Perbedaan kemampuan pemecahan masalah matematika pada kelompok di atas menunjukkan kelompok CTL putri lebih unggul, dalam hal ini kaum perempuan lebih mampu menunjukkan eksistensinya dalam dunia pendidikan dengan berbagai prestasi baik dari proses pembelajaran lebih aktif dibanding dengan kelompok CTL putra, meskipun dalam banyak hal antara laki-laki dan perempuan mempunyai lebih banyak kesamaan daripada perbedaan, namun tidak bisa dipungkiri bahwa gender sebagai karakteristik sebuah budaya yang menggambarkan dua jenis kelamin yang berbeda dalam lingkup perbedaan individu yang sifatnya universal dan memiliki identitas yang berbeda-beda dipengaruhi oleh faktor-faktor ideology, politik, ekonomi, sosial budaya, agama, etnik, adat istiadat, golongan, faktor sejarah, waktu dan tempat serta kemajuan ilmu pengetahuan dan teknologi.

\section{Daftar Pustaka}

Campbell, P. B \& Storo, J. N. (2007). Girls are... boys are...: myths, stereotypes \& gender differences. Office of Educational Research and Improvement. U. S. Department of Educational: Richard W Riley, Secretary. Diambil tanggal 17 februari 2010, dari http://www.campbellkibler.com/Stereo.pdf

Distrik, I, W. (2009). Pembelajaran berdasarkan masalah dengan metode inkuiri untuk meningkatkan konsepsi-konsepsi, aktivitas dan hasil belajar sains siswa SMP. Diambil tanggal 28 januari 2010, dari http://pustakailmiah.unila.ac.id/wp-content/uploads/2009/07/IWayan-Distrik-PEMBELAJARAN-BERDASARKANMASALAH1.pdf

Ebel, R. L \& Frisbie, D. A. (1986). Essentials of educational measurement: 4_ed. University of Lowa, United States of America. Prentice-Hall, Inc. 
52 | Pengaruh Model Pembelajaran Contextual Teaching and Learning (CTL) Dalam Meningkatkan Kemampuan Pemecahan Masalah Matematika Siswa MTs Nurul Hakim Kediri Ditinjau dari Segi Gender

Ghozali, I. (2008). Desain penelitian eksperimental: teori,konsep dan analisis data dengan SPSS 16.0. Semarang, Badan Penerbit Universitas Diponegoro.

Jensen, E. (2008). Brain-based learning_edisi revisi. (Terjemahan Narulita Yusron). California: A SAGE Publications Company. (Buku asli diterbitkan tahun 2007)

Santyasa, I. W. (2008). Pembelajaran berbasis masalah dan pembelajaran kooperatif. Diambil pada tanggal 28 januari $2010 \quad$ dari http://www.freewebs.com/santyasa/pdf2/PROBLEM BASED LEAR NING.pdf

Sudarman. (2009). Peningkatan profesionalisme tenaga pengajar sebagai kontribusi peningkatan mutu pembelajaran. Diambil tanggal 28 januari 2010, dari http://jurnaljpi.files.wordpress.com/2009/09/vol-3-no-1-sudarman.pdf

Sulistyorini. (2009). Evaluasi pendidikan dalam meningkatkan mutu pendidikan. Yogyakarta: Penerbit Teras.

Johnson, E. B. (2002). Contextual teaching and learning. California : Corwin Press,Inc.

Muijs, D \& Reynolds, D. (2005). Effective teaching: evidence and practice_2 $2^{\text {nd }}$ ed. London: SAGE Publications, Ltd.

NCTM. (2000). Principles and standars for school mathematics. Reston, VA: NCTM.

Van dan Heuvel-Panhuizen. (1998). Realistic mathematics education work in progress.

Diambil pada tanggal 9 november 2008 dari

(http://www.fi.uu.nl/en/rme/progress.html).

Walle, J. A. (1994). Elementary school mathematics: teaching developmentally $\left(2^{\text {nd }}\right.$ ed). New York: Longman Publishing.

Wiersma, W. (1986). Research methods in education: an introduction_4 $4^{\text {ed }}$. Unite State of America: Allyn and Bacon, Inc.

Yongge, W. (2005). Improving advanced mathematics teaching by adding some modern methods and ideas. 